\title{
European Journal of Physical Education and Sport Science
}

ISSN: $2501-1235$

ISSN-L: 2501 - 1235

Available on-line at: $\underline{\text { www.oapub.org/edu }}$

\section{THE EFFECT OF CONDUCTING SPORTS ON IMAGERY AND TRAIT ANXIETY LEVELS OF UNIVERSITY STUDENTS}

\author{
Selmani Abişsi, \\ Coşkun Yilmaz ${ }^{2}$, \\ Mehmet Abiş ${ }^{3}$ \\ ${ }^{1}$ Gümüşhane Üniversitesi, \\ Beden Eğitimi ve Spor Yüksekokulu, \\ Gümüşhane, Turkey \\ ${ }^{2}$ Gümüşhane Üniversitesi, \\ Kelkit Aydın Doğan MYO, \\ Gümüşhane, Turkey \\ 3İstanbul Gedik Üniversitesi, \\ Lisansüstü Eğitim Enstitüsü, \\ Istanbul, Turkey
}

\begin{abstract}
:
Our study aim is the study the effect of doing sports on imagery and trait anxiety in university students. The relational scanning model was used in this study, which examined the imagery and trait anxiety relationship of university students who do sports and those who do not. The universe of the research; while creating OMU, 371 active students participated in the sample group in the 2019-2020 academic year. The participants were administered a personal information form (6) developed by the researchers, the imagery Inventory developed by Hall, Mack, Paivio, and Hausenblas (1998), and the Trait Anxiety Scale (20) developed by Spielberger, Goursuch, and Lushene (1970). Gender was found to affect the imagery sub-dimensions $(p<0.05)$ and trait anxiety $(p=0.007)$. While doing sports had no effect on imagery $(p>0.05)$, it was observed that it affected trait anxiety $(p=0.003)$. Alcohol use had no effect on imagery and trait anxiety $(p>0.05)$. While smoking affected the general motivation $(p=0.05)$ in the imagination levels, it did not affect the other imagery states and trait anxiety $(p>0.05)$. While it affected the cognitive $(p=0.004)$ and motivational specific $(p=0.008)$ sub-dimensions at imagination levels with age, it did not affect the general motivation and mastery subdimensions ( $p>0.05)$. Age had an effect on trait anxiety levels $(p=0.04)$. It has been found that gender and age affect imagery and trait anxiety. It has been found that alcohol and cigarette use did not affect it. While doing sports has no effect on imagery, it has been found that it affects trait anxiety.
\end{abstract}

${ }^{i}$ Correspondence: email selmani29@hotmail.com, coskun.yilmaz@gumushane.edu.tr 
Keywords: sport; imagery, trait anxiety

\section{Introduction}

Imagination is creating an experience in the mind using all the senses. In other words, an image should be created in the mind without external stimuli, an image containing one or more senses (Kaya, 2010). According to Weinberger and Gould (2015), imagination is actually a kind of imitation and simulation. It is similar to a sensory experience experienced in real life (such as seeing, feeling, or hearing) but the whole experience is experienced in the mind.

Although imagination is a mental process, it is also an excellent way to develop motor skills. It is very important for athletes to establish positive images in their minds in order to be successful and to benefit from imagination sufficiently. Because positive images also positively affect the actions of athletes (Kızıldağ, 2007). It is possible through imagination in mental experiments towards future performance, not just specific to the past or the present (Andersen, 2000). According to the opinion of many psychologists, imagination is one of the most important studies in improving the psychological performance of the athlete (Hall et al., 1990; Özerkan, 2004; Munzert \& Krüger, 2013).

Imagination is an application that increases or decreases the level of arousal. Visualizing a successful performance can give positive results to the muscular tension and anxiety level in the body. In addition, it is used in the planning made by the athlete and to help the athletes to overcome the problems and situations that may affect the anxiety level by successfully visualizing these plans (Morris et al., 2005).

Anxiety can negatively affect individuals' ability to make the right decisions in their behavior. As the anxiety level rises, the individual gets away from being able to make the right decision and demonstrate his abilities. Individuals who are under extreme pressure can make some wrong moves. Excessive anxiety can make an individual forget even the movements he / she makes continuously, as well as causing confusion in their emotions and making some negative actions (Gümüş, 2002). The aim of our study is to examine the effect of doing sports on imagination and trait anxiety in university students.

\section{Method}

\subsection{Research Model}

The relational screening model was used in this study, in which the imagination and trait anxiety relationship of university students who do sports and those who do not do sports is examined. Relational scanning model; It is a research model that aims to determine the existence and degree of co-change between two or more variables (Karasar, 2002).

\subsection{Data Collection}

There are several practical rules for sample size in the literature. One of them was taken into consideration the proposal that "sample size in scale studies should be at least 5 times of 
each scale item" (Tavşancıl, 2014). For this reason, the Trait Anxiety Scale in the scales for determining the sample of the study consists of 20 questions, and the Imagination in Sports Inventory consists of 21 questions. Although there is a minimum of 205 participants formed by the number of scales, the maximum number of people that can be reached in order to eliminate possible problems was determined and 371 people were reached. Participants who were actively continuing their education at Ondokuz Mayis University in the 2019-2020 academic year were first administered a personal information form (5), then the imagination inventory in sports (21) and finally the trait anxiety scale (20).

\subsection{Data Collection Tools}

\subsubsection{Imagery Inventory}

The original imagery scale to be used in the research was developed by Hall, Mack, Paivio, and Hausenblas (1998). A new expression was not developed by Kizıldağ and Tiryaki (2012) in the process of translating the Inventory into Turkish, and the original form of the inventory was completely adhered to. As a result of the factor analysis, it was seen that the inventory consisted of 4 factors and 21 items.

\subsubsection{Trait Anxiety Inventory}

The Trait Anxiety Inventory developed by Spielberger, Goursuch, and Lushene (1970) was used in the study to measure trait anxiety levels. The scale, which is a type of selfevaluation, includes 20 items consisting of short expressions. The scale was created as a "trait anxiety form" to determine what is generally felt. The score obtained from the scale varies between 20-80. A big score indicates a high anxiety level, a small score indicates a low anxiety level (Öner, 1997).

\subsubsection{The Personal Information}

It was made by the researcher and contains demographic information to be associated with the subject. In the personal information form; there are questions of age, gender, exercise status, smoking, and alcohol use. While the Cronbach's alpha reliability value for the imagery scale used in our study was 870 , it was measured as 744 in the trait anxiety scale.

\subsection{Data Evaluation}

The analysis of the data obtained in the study was made in the SPSS $21.0 \mathrm{~V}$ statistical package program. The normality assumption of the data obtained in the study was evaluated by the Kolmogorov-Smirnov test ( $p>0.05$ ). Crosstab distribution, mean, standard deviation, Student-T test, one-way analysis of variance (One-way ANOVA), and Tukey test were used for the difference between groups. 


\section{Result}

Table 1: Identifying information

\begin{tabular}{|c|c|c|c|c|}
\hline & & & & Total \\
\hline & & Female & Male & \\
\hline Age & $27-30$ & 14 & 26 & 40 \\
\hline & $23-26$ & 55 & 106 & 161 \\
\hline & $18-22$ & 87 & 83 & 170 \\
\hline Body weight & $40-60$ & 96 & 31 & 127 \\
\hline & $61-80$ & 59 & 154 & 213 \\
\hline & $81-100$ & 1 & 24 & 25 \\
\hline & $101+$ & 0 & 6 & 6 \\
\hline Grade level & 1,00 & 23 & 51 & 74 \\
\hline & 2,00 & 32 & 65 & 97 \\
\hline & 3,00 & 57 & 50 & 107 \\
\hline & 4,00 & 44 & 49 & 93 \\
\hline Playing Sports status & Yes & 70 & 126 & 196 \\
\hline & No & 86 & 89 & 175 \\
\hline Smoking & Yes & 67 & 91 & 158 \\
\hline & No & 89 & 124 & 213 \\
\hline Alcohol use & Yes & 54 & 80 & 134 \\
\hline & No & 102 & 135 & 237 \\
\hline Total & & 156 & 215 & 371 \\
\hline
\end{tabular}

In the age category of the participants who participated in our study, the highest participation was between the ages of 18-22 (170 people) and 23-26 (161 people), while 213 participants between the ages of $61-80 \mathrm{~kg}$ in body weight participated. 196 of these participants do sports, 175 of them do not. 158 of the participants stated that they smoke, while 213 of them do not. While 134 people stated that they used alcohol, 237 participants stated that they did not. According to the grade levels of the participants, the highest number of participants was in the 3rd grade (107), while the least participant was in the 1st grade.

Table 2: Comparison of gender and trait anxiety and imagery sub-dimensions

\begin{tabular}{|c|c|c|c|c|c|c|}
\hline & & Sex & n. & $X$ & S.S & p. \\
\hline \multirow{8}{*}{ 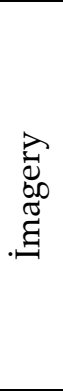 } & \multirow{2}{*}{ Cognitive Imagery } & Female & 156 & 47.41 & 9.71 & \multirow{2}{*}{$\mathrm{p}<.001^{* *}$} \\
\hline & & Male & 215 & 41.93 & 12.90 & \\
\hline & \multirow{2}{*}{ Motivational Specific Imagery } & Female & 156 & 25.90 & 6.34 & \multirow{2}{*}{$\mathrm{p}<.001^{* *}$} \\
\hline & & Male & 215 & 23.32 & 7.13 & \\
\hline & \multirow{2}{*}{ Motivational General-Arousal } & Female & 156 & 20.01 & 5.01 & \multirow{2}{*}{$.05^{*}$} \\
\hline & & Male & 215 & 18.91 & 5.83 & \\
\hline & \multirow{2}{*}{ Motivational General-Mastery } & Female & 156 & 15.93 & 3.98 & \multirow{2}{*}{$.004^{*}$} \\
\hline & & Male & 215 & 14.63 & 4.74 & \\
\hline \multirow{2}{*}{\multicolumn{2}{|c|}{ Trait anxiety }} & Female & 156 & 47.09 & 8.00 & \multirow{2}{*}{$.007^{*}$} \\
\hline & & Male & 215 & 49.22 & 6.78 & \\
\hline
\end{tabular}

** $\mathrm{p}<0.001,{ }^{*} \mathrm{p}<0.05$. 
It was observed that gender affects the imagery sub-dimensions $(p<0.05)$ and trait anxiety $(\mathrm{p}=0.007)$.

Table 3: Comparison of sports and trait anxiety and imagery sub-dimensions

\begin{tabular}{|c|c|c|c|c|c|c|}
\hline & & Playing Sports status & n. & $X$ & S.S & p. \\
\hline \multirow{8}{*}{ 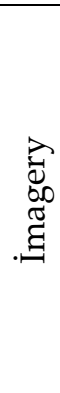 } & \multirow{2}{*}{ Cognitive Imagery } & Yes & 196 & 43.99 & 12.49 & \multirow{2}{*}{.722} \\
\hline & & No & 175 & 44.44 & 11.39 & \\
\hline & \multirow{2}{*}{ Motivational Specific Imagery } & Yes & 196 & 24.37 & 6.97 & \multirow{2}{*}{.923} \\
\hline & & No & 175 & 24.30 & 6.91 & \\
\hline & \multirow{2}{*}{ Motivational General-Arousal } & Yes & 196 & 19.74 & 5.55 & \multirow{2}{*}{.199} \\
\hline & & No & 175 & 18.99 & 5.47 & \\
\hline & \multirow{2}{*}{ Motivational General-Mastery } & Yes & 196 & 15.10 & 4.51 & \multirow{2}{*}{.776} \\
\hline & & No & 175 & 15.24 & 4.49 & \\
\hline \multirow{2}{*}{\multicolumn{2}{|c|}{ Trait anxiety }} & Yes & 196 & 49.43 & 6.55 & \multirow{2}{*}{$.003^{*}$} \\
\hline & & No & 175 & 47.12 & 8.15 & \\
\hline
\end{tabular}

${ }^{* *} \mathrm{p}<0.001,{ }^{*} \mathrm{p}<0.05$.

While doing sports had no effect on imagery ( $p>0.05)$, it was observed that it affected trait anxiety $(\mathrm{p}=0.003$; Table 3$)$.

Table 4: Comparison of alcohol use with trait anxiety and imagery sub-dimensions

\begin{tabular}{|c|c|c|c|c|c|c|}
\hline & & Alcohol use & n. & $X$ & S.S & p. \\
\hline \multirow{8}{*}{ 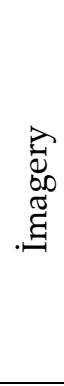 } & \multirow[t]{2}{*}{ Cognitive Imagery } & Yes & 134 & 44.25 & 12.67 & \multirow{2}{*}{.951} \\
\hline & & No & 237 & 44.33 & 11.44 & \\
\hline & \multirow[t]{2}{*}{ Motivational Specific Imagery } & Yes & 134 & 24.13 & 7.25 & \multirow{2}{*}{.541} \\
\hline & & No & 237 & 24.59 & 6.72 & \\
\hline & \multirow[t]{2}{*}{ Motivational General-Arousal } & Yes & 134 & 19.23 & 5.80 & \multirow{2}{*}{.705} \\
\hline & & No & 237 & 19.46 & 5.33 & \\
\hline & \multirow[t]{2}{*}{ Motivational General-Mastery } & Yes & 134 & 15.12 & 4.73 & \multirow{2}{*}{.856} \\
\hline & & No & 237 & 15.21 & 4.32 & \\
\hline \multirow{2}{*}{\multicolumn{2}{|c|}{ Trait anxiety }} & Yes & 134 & 48.78 & 7.87 & \multirow{2}{*}{.320} \\
\hline & & No & 237 & 47.98 & 7.10 & \\
\hline
\end{tabular}

Alcohol use had no effect on imagery and trait anxiety ( $p>0.05$; Table 4$)$.

Table 5: Comparison of smoking trait anxiety and imagery sub-dimensions

\begin{tabular}{|c|c|c|c|c|c|c|}
\hline & & Smoking & n. & $X$ & S.S & p. \\
\hline \multirow{8}{*}{ 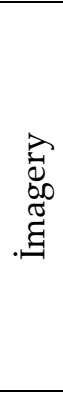 } & \multirow{2}{*}{ Cognitive Imagery } & Yes & 158 & 43.20 & 11.83 & \multirow{2}{*}{.151} \\
\hline & & No & 213 & 45.00 & 12.03 & \\
\hline & \multirow{2}{*}{ Motivational Specific Imagery } & Yes & 158 & 23.63 & 6.94 & \multirow{2}{*}{.062} \\
\hline & & No & 213 & 24.98 & 6.86 & \\
\hline & \multirow{2}{*}{ Motivational General-Arousal } & Yes & 158 & 18.72 & 5.77 & \multirow{2}{*}{$.05^{*}$} \\
\hline & & No & 213 & 19.85 & 5.29 & \\
\hline & \multirow{2}{*}{ Motivational General-Mastery } & Yes & 158 & 14.80 & 4.40 & \multirow{2}{*}{.162} \\
\hline & & No & 213 & 15.46 & 4.52 & \\
\hline \multirow{2}{*}{\multicolumn{2}{|c|}{ Trait anxiety }} & Yes & 158 & 48.66 & 7.67 & \multirow{2}{*}{.444} \\
\hline & & No & 213 & 48.07 & 7.17 & \\
\hline
\end{tabular}

** $\mathrm{p}<0.001,{ }^{*} \mathrm{p}<0.05$. 
While smoking affected the general motivation $(p=0.05)$ in the imagery levels, it did not affect the other imagery states and the state of trait anxiety ( $p>0.05$; Table 5).

Tablo 6: Comparison of age and trait anxiety and imagery sub-dimensions

\begin{tabular}{|c|c|c|c|c|c|c|}
\hline & & Age & n. & $X$ & S.S & p. \\
\hline \multirow{16}{*}{$\begin{array}{l}\vec{D} \\
\infty \\
\vec{\Xi} \\
. \Xi\end{array}$} & \multirow{4}{*}{ Cognitive Imagery } & $27-30^{\mathrm{b}}$ & 40 & 40.65 & 14.73 & \multirow{4}{*}{$.004^{*}$} \\
\hline & & $23-26$ ab & 161 & 42.86 & 12.50 & \\
\hline & & $18-22$ a & 170 & 46.37 & 10.29 & \\
\hline & & Total & 371 & 44.23 & 11.96 & \\
\hline & \multirow{4}{*}{ Motivational Specific Imagery } & $27-30 \mathrm{~b}$ & 40 & 22.48 & 8.49 & \multirow{4}{*}{$.008^{*}$} \\
\hline & & $23-26$ ab & 161 & 23.68 & 6.85 & \\
\hline & & $18-22$ a & 170 & 25.55 & 6.41 & \\
\hline & & Total & 371 & 24.40 & 6.92 & \\
\hline & \multirow{4}{*}{ Motivational General-Arousal } & $27-30$ & 40 & 18.25 & 6.29 & \multirow{4}{*}{.329} \\
\hline & & $23-26$ & 161 & 19.32 & 5.70 & \\
\hline & & $18-22$ & 170 & 19.69 & 5.14 & \\
\hline & & Total & 371 & 19.37 & 5.52 & \\
\hline & \multirow{4}{*}{ Motivational General-Mastery } & $27-30$ & 40 & 14.43 & 4.95 & \multirow{4}{*}{.308} \\
\hline & & $23-26$ & 161 & 15.00 & 4.78 & \\
\hline & & $18-22$ & 170 & 15.52 & 4.04 & \\
\hline & & Total & 371 & 15.18 & 4.48 & \\
\hline \multirow{4}{*}{\multicolumn{2}{|c|}{ Trait anxiety }} & $27-30$ & 40 & 47.13 & 6.47 & \multirow{4}{*}{$.04^{*}$} \\
\hline & & $23-26$ & 161 & 49.42 & 6.79 & \\
\hline & & $18-22$ & 170 & 47.56 & 7.99 & \\
\hline & & Total & 371 & 48.32 & 7.38 & \\
\hline
\end{tabular}

${ }^{* *} \mathrm{p}<0.001,{ }^{*} \mathrm{p}<0.05$

While it affected the cognitive $(\mathrm{p}=0.004)$ and motivational specific $(\mathrm{p}=0.008)$ subdimensions at imagery levels with age, it did not affect the general motivation and mastery sub-dimensions ( $p>0.05)$. Age had an effect on trait anxiety levels $(p=0.04$; Table $6)$.

\section{Discussion}

Paivio (1985) found that cognitive imagery is used for the correct application of skills, while athletes using motivational private imagination are better at maintaining goalrelated tasks. Hall et al. (1998) stated that athletes using the motivational general mastery sub-dimension of imagery are mentally stronger and more controlled. In this context, it can be thought that it will be easier for athletes with low levels of anxiety to form new strategies in their minds, to the imagery that they are stronger than their opponents, and the pride and excitement they will experience in the competition.

White and Hardy (1998) stated that the motivational general arousal subdimension of imagery is used by athletes to control arousal level and anxiety while preparing for a competition. In this context, it can be said that athletes with a high level 
of anxiety will imagine the stress and anxiety they will experience during the match more in their minds in order to keep their arousal levels under control.

It was observed that gender affects the imagery sub-dimensions $(\mathrm{p}<0.05)$ and trait anxiety $(p=0.007)$. When Kartal et al. (2017) examined the difference between the genders of the participants and the imagery sub-dimensions, it was found that there was no statistically significant difference between all sub-dimensions ( $p>0.05$ ). In the study conducted by Kizıldağ (2007) on athletes engaged in different sports branches, a significant difference was found between female and male athletes' cognitive imagery, Motivational Special Imagery, and Motivational General Aroused sub-dimensions. Tekin (2018) observed that there is no significant difference between gender and imagery skills (cognitive imagery, motivation-specific imagination, motivational general-arousal, motivational general-mastery). In the study of Başaran et al. (2009), no statistically significant difference was found between trait anxiety scores of male and female subjects (Özbekçi, 1989; Engür, 2002; Öğüt, 2000; Öğüt, 2004; Develi, 2006). Özgül (2003) found that Trait Anxiety scores were significantly higher in girls.

While doing sports did not affect imagery ( $p>0.05)$, it was observed that it affected trait anxiety $(p=0.003)$.

Alcohol use did not affect imagery and trait anxiety ( $p>0.05)$. Contrary to our study, Turhan et al. (2011) reported a relationship between alcohol use and high trait anxiety.

While smoking affected the general motivation $(p=0.05)$ in the imagery levels, it did not affect the other imagery states and the state of trait anxiety ( $p>0.05)$. Turhan et al. (2011), in which different results were obtained with our study, reported that there was a relationship between smoking and high trait anxiety. Özdemir et al. (2017) reported that the trait anxiety levels of pregnant women who smoke in both periods are higher than non-smoking participants.

While age affected the cognitive $(p=0.004)$ and motivational specific $(p=0.008)$ sub-dimensions in the imagery levels, there was no effect on the general motivation and mastery sub-dimensions ( $p>0.05)$. Age also had an effect on trait anxiety levels $(p=0.04)$. Güvendi, (2015), when the difference between the age groups of the participants and the imagery sub-dimensions was examined, it was found that there was a significant difference in motivational general mastery levels $(p<0.05)$, while no significant difference was found between the other sub-dimensions ( $\mathrm{p}>0.05)$.

When Kartal et al. (2017) examined the difference between the age groups and imagery sub-dimensions of the participants, it was found that there was no statistically significant difference ( $p>0.05)$. According to the research of Parker and Lovell (2012), they found that the 20-21 age group had higher visual acuity scores than the 12-13 age group participants. In the study conducted by Güvendi et al. (2016), a significant difference was observed between age groups and imagery only in the motivational general mastery sub-dimension. Tekin (2018) observed that there is a significant difference in the motivation-specific imagery sub-dimension of age and imagination skills. However, it is observed that there is no significant difference between the 
performance levels of archers and their imagination skills in cognitive imagery, motivational general-arousal, and motivational general-mastery sub-dimensions.

\section{Conclusion}

As a result, it was found that while gender, age, and smoking affect imagery levels, sports and alcohol use do not. While trait anxiety was affected by gender, sports, age, alcohol, and smoking were not observed.

\section{Ethical Statement}

Scientific, ethical, and quotation rules were followed in the writing process of our study titled "The effect of doing sports on the visualization and constant anxiety of university students"; no falsification has been made on the collected data and this study has not been sent to any other academic publication environment for evaluation. The decision of the ethics committee of the study was taken with the approval of the Scientific Research and Publication Ethics Board of Gümüşhane University, numbered E-95674917-108.99-1441, at the meeting dated 06/01/2021 and numbered 2020/12.

\section{Conflict of Interest Statement}

The authors declare no conflicts of interests.

\section{About the Author}

Research Assistant Selmani Abis, Gümüşhane University, Physical Education and Sports High School, Exercise and Sport Psychology. orcid.org/0000-0002-0322-518X.

Lecturer Coşkun Yilmaz, Gümüşhane University, Kelkit Aydın Doğan Vocational High School. Exercise Physiology, Exercise and Sport Psychology. orcid.org/0000-0002-2826$\underline{1566 .}$.

PhD student Mehmet Abiş, Istanbul Gedik University, Graduate Education Institute, Exercise and Sport Psychology. https://orcid.org/0000-0002-7394-9714.

\section{References}

Andersen, M. B. (2000). Doing sport psycologhy. United States: Human Kinetics, s. 83.

Başaran, M. H., Taşğın, Ö., Sanioğlu, A. \& Taşkın, A. K. (2009). Sporcularda durumluk ve sürekli kaygı düzeylerinin bazı değişkenlere göre incelenmesi. Selçuk Üniversitesi Sosyal Bilimler Enstitüsü Dergisi, 2(1),541.

Develi E. (2006). Konya'da ilköğretim Okullarında Görev Yapan Beden Eğitimi öğretmenlerinin Sürekli Kaygı Durumlarının incelenmesi, Selçuk University, Master Thesis, Konya.

Engür, M. (2002). Elit Sporcularda Başarı Motivasyonun, Durumluk Kaygı Düzeyleri Üzerine Etkisi, Ege University, Master Thesis, İzmir. 
Gümüş, M. (2002). Profesyonel futbol takımlarında puan sıralamasına göre durumluk kaygı düzeylerinin incelenmesi. Sakarya University, Master Thesis, Sakarya.

Güvendi, B. (2015). Elit akademi ligi futbolcularında imgeleme ve kayg ilişkisinin incelenmesi. Gazi University, Master Thesis, Ankara.

Güvendi, B., Bilgin, U. (2016). Elit akademi ligi futbolcularında imgeleme ve kayg1 ilişkisinin incelenmesi. Uluslararası Hakemli Psikiyatri Ve Psikoloji Araştırmaları Dergisi,7:69-70.

Hall C. R., Rodgers W., Barr K. A. (1990). The Use of Imagery by Athletes in Selected Sports. International Journal of Sport Psychology, 4(1), 1-10.

Hall, C. R., Mack, D., Paivio, A., Hausenblas, H. (1998). Imagery use by athletes: Development of the sport imagery questionnaire. International Journal of Sport Psychology, 29,73-89.

Karasar, N. (2015). Bilimsel Araştırma Yöntemi. Ankara: Nobel Yayın Dağıtım

Kartal, Z., Güvendi, B., Türksoy, A. \& Altıncı, E. E. (2017). Takım sporcularının imgeleme kullanımları ile başarı motivasyonları arasındaki ilişki. İstanbul Üniversitesi Spor Bilimleri Dergisi, 7(1), s. 47-48

Kaya, F. (2010). Performans için imgeleme, http://performansgelistirme.blogspot.com.tr, Erişim Tarihi: 28.12.2020.

Kızıldağ, E. (2007). Farklı spor branşlarındaki sporcuların imgeleme biçimleri. Mersin University, Master Thesis, Mersin.

Kızıldağ E., Tiryaki M. Ş. (2012). Sporda imgeleme envanterinin türk sporcular için uyarlanması, Hacettepe Üniversitesi Spor Bilimleri Dergisi, 23 (1), 13-23.

Munzert, J., Krüger, B. (2013). Motor and Visual Imagery in Sports, Multisensory Imagery, s. 334-335.

Morris, T., Spittle M., Watt P. A. (2005). Imagery in sport. Human Kinetics. s. 225.

Paivio, A. (1985). Cognitive and motivational functions of imagery in human performance. Canadian Journal of Applied Sport Sciences, 10(4), 22- 28.

Parker, J. K., Lovell, G. P. (2012). Age differences in the vividness of youth sport performers' imagery ability. J Imagery Res Sport Phys Activ. 7(1), 1-13.

Spielberger, C. D., Goursuch, R. L., Lushene, R. E. (1970). Manual for state-trait anxiety inventory. California: Consulting Psych-Press.

Öner, N. (1997). Durumluluk sürekli kaygı envanterinin türk toplumunda geçerliliği. Doçentlik Tezi, Hacettepe University, Ankara.

Öğüt, F. (2000). Sosyal Uyum ile Sürekli Kaygı Arasındaki ilişki, Kocaeli University, Master Thesis, Kocaeli.

Öğüt, R. (2004). Sporda Sürekli Kaygı Düzeyi ile Benlik Saygısının Karşılaştırılması, Ege University, Master Thesis, İzmir.

Özbekçi, F. (1989). Farklı Spor Dallarında Yaşanan Müsabaka Stres Düzeylerinin Araştırılması, Marmara University, Master Thesis, İstanbul.

Özdemir, N., Yalçın, S., Kariptaş, E. (2019). Demografik Özellikler ve Sigara İçme Durumu Açısından Gebelerin Doğum Öncesi ve Sonrası Durumluk ve Sürekli 
Kayg1 Düzeylerinin İncelenmesi. Ahi Evran Üniversitesi Sağlık Bilimleri Fakültesi Să̆lık Bilimleri Dergisi 2(3), 34-45

Özerkan, K. N. (2004). Spor psikolojisine giriş temel kavramlar. Ankara: Nobel Yayın Dağıtım (1. Bask1), s. 81, 82, 122.

Özgül, F. (2003). Beden Eğitimi ve Spor Yüksek Okulu Öğrencilerinde Durumluk ve Sürekli Kaygı Düzeyleri, Cumhuriyet University, Master Thesis, Sivas.

Tekin, M. (2018). Okçuların imgeleme becerileri ile dikkat ve performans düzeyleri arasındaki ilişkinin incelenmesi, Aydın Adnan Menderes University, Master Thesis, s: 31-4446, Aydin.

Turhan, E., İnandı, T., Özer, C., Akoğlu, S. Üniversite Öğrencilerinde Madde Kullanımı, Şiddet ve Bazı Psikolojik Özellikler. Türkiye Halk Să̆lı̆̆ı Dergisi 2011:9(1):33-44.

Weinberger, R. S., Gould, D. Spor ve egzersiz psikolojisinin temelleri. Human Kinetics, Ankara: Nobel Akademik Yayıncılık, 6. Bask1, 2015;77-302.

White, A., Hardy, C. (1998). An in-depth analysis of the uses of imagery by high-level slalom canoeists and artistic gymnasts. The Sport Psychologist, 12, 387-403. 

be applied to their work. Under the terms of this license, no permission is required from the author(s) or publisher for members of the community to copy, distribute, transmit or adapt the article content, providing a proper, prominent and unambiguous attribution to the authors in a manner that makes clear that the materials are being reused under permission of a Creative Commons License. Views, opinions and conclusions expressed in this research article are views, opinions and conclusions of the author(s). Open Access Publishing Group and European Journal of Physical Education and Sport Science shall not be responsible or answerable for any loss, damage or liability caused in relation to/arising out of conflict of interests, copyright violations and inappropriate or inaccurate use of any kind content related or integrated on the research work. All the published works are meeting the Open Access Publishing requirements and can be freely accessed, shared, modified, distributed and used in educational, commercial and non-commercial purposes under a Creative Commons attribution 4.0 International License (CC BY 4.0). 